\title{
UNIVERSITY OF WISCONSIN RADIOCARBON DATES IX
}

\author{
MARGARET M. BENDER, REID A. BRYSON, and \\ DAVID A. BAERREIS
}

Department of Meteorology

University of Wisconsin, Madison

Radiocarbon dates obtained since December, 1969, are summarized here. Procedures and equipment have been described previously (R., 1966 , v. 8 , p. 522). Wood, charcoal, and peat samples are pretreated with dilute $\mathrm{NaOH}$ and dilute $\mathrm{H}_{3} \mathrm{PO}_{4}$ before conversion to the counting gas, methane; marls and lake cores are treated with acid only. Very calcareous materials are treated with $\mathrm{HCl}$ instead of $\mathrm{H}_{3} \mathrm{PO}_{4}$.

The dates reported have been calculated using 5568 years as the half-life of $\mathrm{C}^{14}$, with 1950 as the reference year. The standard deviation quoted includes only the $1 \sigma$ of the counting statistics of background, sample, and standard counts. The $\mathrm{C}^{13} / \mathrm{C}^{12}$ ratios of the $\mathrm{CO}_{2}$ samples prepared from NBS oxalic acid are measured and the activity of the methane used as standard is corrected for any deviation of the $\delta \mathrm{C}^{13}$ value of the $\mathrm{CO}_{2}$ from the $-19 \%$ value (compared to the PDB standard) reported by Craig (1961). The dated samples for which $\delta \mathrm{C}^{13}$ values are reported have been corrected to $-25.0 \%$ (PDB standard), the "normal" value of terrestrial material.

\section{ACKNOWLEDGMENTS}

This research is supported by the National Science Foundation, Atmospheric Sciences Division, Grant GA-10651X. We thank the Chemistry Department for the use of the Nuclide RMS-660 mass spectrometer and Gary Parr and William Stebbings for technical assistance with the mass spectrometer.

\section{ARCHAEOLOGIC SAMPLES}

\section{A. Illinois}

\section{Cahokia, Monk's Mound}

Wood charcoal from Monk's Mound, Cahokia site, Madison Co., Illinois ( $38^{\circ} 40^{\prime} \mathrm{N}$ Lat, $90^{\circ} 04^{\prime} \mathrm{W}$ Long). Coll. 1967 and 1969 and subm. by M. L. Fowler, Univ. of Wisconsin-Milwaukee.

WIS-443. Cahokia, Monk's Mound A.D. 1280

$670 \pm 55$

Sample 69-847 from 1st terrace of Monk's Mound, Feature 113, N74-76, E102-104. Post 1 centered at N72.23, E103.19.

\section{WIS-444. Cahokia, Monk's Mound} $750 \pm 55$

Sample 67-388, burned post (E461.80-461.87, N327.65-327.70), from Feature 28. Post was found standing upright in trench fill of stockade $\mathrm{E}$ of Monk's Mound. This is latest stockade in sequence with open bastion. 
WIS-447. Cahokia, Monk's Mound

$$
1015 \pm 60
$$

Sample 69-900 from pit, Mound 72, S841-845, E58-60, at $+126 \mathrm{~m}$. An irregular accumulation of debris, pottery, stone, and bone intruded into the earlier excavation of Feature 205. Pit was later used for burial of 22 individuals.

\section{B. Iowa}

\section{WIS-393. A. C. Banks site (13PM40)}

$$
3680 \pm 65
$$

1730 B.c. Lat, $96^{\circ} 37^{\prime} \mathrm{W}$. A Lat, $96^{\circ} 37^{\prime} \mathrm{W}$ Long). Coll. 1967 by R. Banks and D. A. Baerreis; subm. by D. A. Baerreis. Sample from 196 to $226 \mathrm{~cm}$ depth. Previous date, WIS285, 3860 B.P., was obtained from charcoal of $198 \mathrm{~cm}$ depth (R., 1969, v. 11, p. 229). Date confirms earlier run and indicates cultural horizon is Archaic.

\section{WIS-397. Jackson County, Iowa (13JK20)}

$1130 \pm 60$

Charcoal from Henry Schnoor Rock Shelter on Maquoketa R. in Jackson Co., Iowa $\left(42^{\circ} 10^{\prime} \mathrm{N}\right.$ Lat, $90^{\circ} 48^{\prime} \mathrm{W}$ Long). Coll. 1969 by $\mathrm{M}$. Jaehnig, Univ. of Wisconsin-Madison; subm. by D. A. Baerreis. Sample from Level 5, Sq. N5B, 48.3 to $63.5 \mathrm{~cm}$ deep. Dates bundle burial of young child. Other dates from site were pub. previously (R., 1970, v. 12, p. 336).

\section{WIS-406. Robert Battey Rock Shelter (13JK21) $970 \pm 60$}

Charcoal from site in town of South Fork, Jackson Co., Iowa $\left(42^{\circ}\right.$ $07^{\prime} \mathrm{N}$ Lat, $90^{\circ} 47^{\prime} \mathrm{W}$ Long). Coll. 1969 by M. Jaehnig; subm. by D. A. Baerreis. Dates from this site, WIS-398-401, were pub. earlier (R., 1970, v. 12, p. 640-641). Sample from F $17,259 \mathrm{~cm}$ down slope from rock shelter, Level 4, 30.5 to $41 \mathrm{~cm}$ below surface. Area seems to be separate occupation from rock shelter and it should date back to Archaic or Early Middle Woodland period. Artifacts are almost exclusively lithic with lanceolate to side-notched projectile points occurring as opposed to large variety of projectile points in shelter itself.

\section{Bartron site (21GD2)}

\section{Minnesota}

Charcoal from Bartron site on S tip of Prairie I. in Mississippi R., Goodhue Co., Minnesota (44 $37^{\prime} \mathrm{N}$ Lat, $92^{\circ} 39^{\prime} \mathrm{W}$ Long). Coll. 1969 by Elden Johnson, Univ. of Minnesota; subm. by D. A. Baerreis. Site is Oneota habitation site, classified as Blue Earth focus by Wilford (1955) and related to Silvernale, Bryan, and Mero sites, located within $16 \mathrm{~km}$ radius from Bartron. 
WIS-423. Bartron site (21GD2)

$850 \pm 55$

Sample (Accession no. 671-241) from Feature 76, a pit, $20 \mathrm{~cm}$ depth, at 39.85 to $41.55 \mathrm{~N}, 3-4.12 \mathrm{~W}$. Assoc. with animal bone, sherds, antler.

W/IS-434. Bartron site (21GD2)

$\mathbf{8 9 0} \pm \mathbf{5 5}$

Sample (Accession no. 671) from Feature 39, fire pit, $40 \mathrm{~cm}$ depth, $41.65 \mathrm{~N}, 0.5 \mathrm{E}$. Assoc. with pottery sherds, clam shell, animal bone, rock.

\section{Wisconsin}

\section{WIS-426. Brogley Rock Shelter (47GT156)}

$$
1890 \pm 60
$$

Charcoal from Brogley rock shelter in Grant Co., Wisconsin $\left(42^{\circ}\right.$ $45^{\prime} \mathrm{N}$ Lat, $90^{\circ} 37^{\prime} \mathrm{W}$ Long) during excavation in 1969 by R. H. Nelson, Platteville, Wisconsin; subm. by D. A. Baerreis. Sample (5W-105) from 112 to $117 \mathrm{~cm}$ below surface in Level 5 .

\section{E. Oklahoma}

$$
730 \pm 55
$$

WIS-448. Creek site (D1-41)

Charcoal from Lillie Creek site ( $36^{\circ} 30^{\prime} \mathrm{N}$ Lat, $94^{\circ} 59^{\prime} \mathrm{W}$ Long) in Delaware Co., Oklahoma, coll. 1940 and subm. by D. A. Baerreis. Sample from Level 1, 0 to $10 \mathrm{~cm}$ below plow zone. Date agrees well with earlier date from site, A.D. 1190, WIS-42 (R., 1965, v. 7, p. 403), and implies rapid construction of subsequent mound addition.

\section{WIS-449. Weston site (Os 99)}

$960 \pm 60$

Charcoal from Weston site, Osage Co., Oklahoma $\left(36^{\circ} 54^{\prime} \mathrm{N}\right.$ Lat, $95^{\circ} 55^{\prime} \mathrm{W}$ Long) coll. 1969 by James Howard, Oklahoma State Univ., Stillwater, Oklahoma; subm. by D. A. Baerreis.

\section{Canyon Country Club Cave}

$$
\text { F. Texas }
$$

Samples from Canyon Country Club Cave, Randall Co., Texas (Panhandle Plains Historical Mus. Site No. A251) $\left(35^{\circ} 0^{\prime} \mathrm{N}\right.$ Lat, $102^{\circ}$ $58^{\prime} 42^{\prime \prime}$ W Long). Coll. 1956 by Jack T. Hughes; subm. by D. A. Baerreis.

WIS-410. Canyon Country Club Cave

Charcoal, Specimen 312, from Sq. N-2/N-S, Level 1.

WIS-411. Canyon Country Club Cave

Charcoal, Specimen 183, from Sq. N-1/W-1, Level 1.

WIS-403. Canyon Country Club Cave

Charcoal, Specimen 196, from Sq. N-1/W-1, Level 2.

$$
400 \pm 60
$$

A.D. 1550

$300 \pm 50$

A.D. 1650

$670 \pm 50$ 
WIS-421. Canyon Country Club Cave

Charcoal, Specimen 53, from Sq. N-S/N-1, Level 2.

WIS-402. Canyon Country Club Cave

Charcoal, Specimen 306, from Sq. E-W/W-1, Level 3.

WIS-408. Canyon Country Club Cave

Charcoal, Specimen 217, from Sq. N-1/W-1, Level 3.

WIS-404. Canyon Country Club Cave

Charcoal, Specimen 309, from Sq. E-W/W-1, Level 4.

\section{WIS-414. Canyon Country Club Cave}

Charcoal, Specimen 395, from Sq. S-2/W-1, Level 4.

WIS-394. Canyon Country Club Cave

Bones (Bison bison), A25/W, from Level 4.

WIS-412. Canyon Country Club Cave

Charcoal, Specimen 440, from Sq. N-2/E-1, Level 5.

\section{WIS-420. Canyon Country Club Cave}

Charcoal, Specimen 231, from Sq. N-1/W-1, Level 5.

\section{WIS-430. Canyon Country Club Cave}

Charcoal, Specimen 311, from Sq. E-W/W-1, Level 5.

II. GEOLOGIC SAMPLES

\section{A. California}

\section{WIS-413. San Miguel Island, California}

Sample SMI 178, charcoalized small tree (presumably Rhus) id. by R. C. Koeppen, Forest Products Lab., Madison, Wisconsin. Coll. from San Miguel I., California (34 02' N Lat, $120^{\circ} 20^{\prime} \mathrm{W}$ Long) 1969 by D. L. Johnson, Univ. of Kansas, Lawrence; subm. by R. A. Bryson. Tree grew on well-developed soil (paleosol) now overlain by 91.5 to $183 \mathrm{~cm}$ eolianite, $183 \mathrm{~cm}$ weakly developed paleosol with midden, and another eolianite and alluvial unit of variable thickness.

\section{B. Wisconsin}

\section{WIS-409. Iron County, Wisconsin}

$$
10,100 \pm 100
$$$$
8150 \text { B.c. }
$$

Spruce wood, id. by R. C. Koeppen, from 365 to $426 \mathrm{~cm}$ depth in sandy humic layer above clay till at $317 \mathrm{~m}$ elev. in Iron Co., Wisconsin 
(46 $30^{\circ} \mathrm{N}$ Lat, $90^{\circ} 27^{\prime} \mathrm{W}$ Long). Site similar to that of buried wood to NE (Black, 1969, Broecker et al., 1956, Crane, 1956, Hack, 1965) which ranges form ca. 9500 to 12,600 B.P. Coll. 1968 by C. E. Lindsay; subm. by R. F. Black, Univ. of Wisconsin-Madison.

\section{Disterhaft Farm Bog and Seidel Lake, Wisconsin}

Undated pollen diagrams from Disterhaft Farm Bog, Green Lake Co., Wisconsin $\left(43^{\circ} 55^{\prime} \mathrm{N}\right.$ Lat, $89^{\circ} 10^{\prime} \mathrm{W}$ Long) and Seidel Lake, Kewaunee Co., Wisconsin (44 $26^{\prime} 43^{\prime \prime} \mathrm{N}$ Lat, $87^{\circ} 31^{\prime} 36^{\prime \prime} \mathrm{W}$ Long) provided 1st detailed pollen stratigraphy for Wisconsin (West, 1961). The Disterhaft site lies on Cary (Woodfordian) till and should date from retreat of Cary ice; the Seidel site lies on what is presumed Valders drift. Disterhaft Farm Bog was cored again in 1965 by H. E. Wright, E. J. Cushing, and J. K. Wasylikowa, and an $878 \mathrm{~cm}$ core was given to R. G. Baker for pollen analysis. The new pollen diagram closely supports West's 1961 diagram. Samples date pollen zone boundaries; subm. by R. G. Baker, Univ. of Wisconsin-Madison.

\section{WIS-422. Disterhaft Farm Bog}

$2850 \pm 65$

Brown fibrous peat from 200 to $210 \mathrm{~cm}$ of $878 \mathrm{~cm}$ core. Dates rise in Betula, Tsuga, and Sphagnum at base of Pollen Zone 8, uppermost zone.

\section{WIS-427. Disterhaft Farm Bog}

Brown fibrous peat from 390 to $397 \mathrm{~cm}$ depth. Dates fall of Uh. pollen and rise of Gramineae and Cyperaceae pollen at base of Pollen Zone 7 .

\section{WIS-429. Disterhaft Farm Bog}

$$
\mathbf{8 4 8 0} \pm \mathbf{8 5}
$$

Olive-gray gyttja from 520 to $530 \mathrm{~cm}$ interval of core. Dates decline of Pinus pollen and rise of Quercus pollen at base of Pollen Zone 6.

\section{WIS-441. Disterhaft Farm Bog}

$$
11,150 \pm 160
$$

Olive-gray gyttja from 665 to $675 \mathrm{~cm}$ interval of core. Dates rise in Pinus pollen and decline in Picea pollen at base of Pollen Zone 5.

\section{WIS-457. Disterhaft Farm Bog}

\section{Wandy calcareous gyttja from 770 to $780 \mathrm{~cm}$ interval of core. Dates} beginning of slight decline of Picea and maximum of Artemisia pollen in late-glacial time.

\section{WIS-442. Disterhaft Farm Bog}

$15,560 \pm 150$

Sandy olive-gray gyttja from 868 to $878 \mathrm{~cm}$ interval. Dates retreat of Woodfordian (Cary?) ice from Green Lake Co., Wisconsin, and initial establishment of late-glacial Picea forest. 


\section{WIS-462. Seidel Lake}

Silty mud with detritus and nodules of limestone, 1417 to $1442 \mathrm{~cm}$ depth from core of $1574 \mathrm{~cm}$. Date is inconsistent with identification of till as Valders.

\section{WIS-445. Cold Spring Peat Mound}

$10,800 \pm 110$

Core of $100 \mathrm{~cm}$ obtained in 1969 from peat mound in Jefferson Co., Wisconsin (42 $54^{\prime} \mathrm{N}$ Lat, $88^{\circ} 36^{\prime} \mathrm{W}$ Long), by T. Webb and R. G. Baker. Sample dated was dark brown bryophytic peat 55 to $58 \mathrm{~cm}$ below surface of mound, from just above break in stratigraphy from upper layer of brown bryophytic to black fine-grained peat. Lower layer contains Picea pollen and Picea wood fragments and extends $42 \mathrm{~cm}$ to bottom of mound which rests on layer of sand. Earlier date from base of mound was 12,800 B.P., WIS-48, (R., 1965, v. 7, p. 407).

\section{WIS-425. Lake Wingra Fen}

$8570 \pm 90$

Core of $4.5 \mathrm{~m}$ obtained 1969 by R. G. Baker and T. Webb, Univ. of Wisconsin-Madison, from Lake Wingra Fen, Dane Co., Wisconsin $\left(43^{\circ}\right.$ $03^{\prime} \mathrm{N}$ Lat, $89^{\circ} 26^{\prime} \mathrm{W}$ Long). Sample dated was detrital peat with snail shells from 265 to $280 \mathrm{~cm}$ interval in core. Sharp contact between peat and marl occurs at $280 \mathrm{~cm}$ depth. Pollen evidence indicates that contact represents hiatus of a few thousand yr; late-glacial spruce pollen occurs in marl and mid-postglacial grass-oak occurs in lowest peat.

\section{Lake Mary, Wisconsin}

Sediment core, $248 \mathrm{~cm}$ length, from center of meromictic Lake Mary, Vilas Co., Wisconsin (46 $16^{\circ} 15^{\prime} \mathrm{N}$ Lat, $89^{\circ} 54^{\prime} \mathrm{W}$ Long) coll. 1962 by G. Likens, Dartmouth College, New Hampshire; subm. by R. A. Bryson. Date, 9460 B.P., WIS-371, (R., 1970, v. 12, p. 335-345) for 186 to $201 \mathrm{~cm}$ interval was reported earlier.

\section{WIS-435. Lake Mary, Wisconsin}

$3650 \pm 65$

45.5 to $54 \mathrm{~cm}$ interval in core at level in pollen stratigraphy where birch and hemlock show distinct rise.

\section{WIS-437. Lake Mary, Wisconsin}

$8540 \pm 90$

Sample from 137.5 to $145 \mathrm{~cm}$ interval in core at level where ratio of Pinus strobus pollen to Pinus banksiana/resinosa pollen changes from 1:6 at $145 \mathrm{~cm}$ to $9: 1$ at $135 \mathrm{~cm}$.

\section{Neath site, Wisconsin}

Samples obtained during excavation of mastodon skeleton from peat bog on farm of John Neath, Jr., in Dane Co., Wisconsin $\left(43^{\circ} 04^{\prime}\right.$ $\mathrm{N}$ Lat, $89^{\circ} 07^{\prime} \mathrm{W}$ Long). Coll. 1969 and subm. by J. E. Dallman, Univ. of Wisconsin-Madison. Bulldozing activities covered old ground level to depth of $41 \mathrm{~cm}$. 
$10,790 \pm 105$

WIS-424. Neath site

8840 B.C.

Wood (either tamarack or blue spruce), beaver cuttings, from 117 to $119 \mathrm{~cm}$ depth below old surface in peat level of bog. May indicate time of shift from spruce to mixed hardwood forest.

WIS-431. Neath site

$13,120 \pm 130$

11,170 в.C.

Spruce, id. by Botany Dept., Univ. of Wisconsin-Madison, from large deposit of small diam. trees 246 to $257 \mathrm{~cm}$ below old surface level in bog. This level is $48 \mathrm{~cm}$ below bottom of marl stratum containing mastodon remains.

\section{Blockhouse Creek Drainage Basin}

Samples obtained in 1969 and 1970 in peat deposits exposed by stream cuts below alluvial fan at tributary entrance to flood plain in Blockhouse Creek Drainage Basin, Grant Co., Wisconsin $\left(42^{\circ} 41^{\prime} \mathrm{N}\right.$ Lat, $90^{\circ} 32^{\prime} \mathrm{W}$ Long). Coll. and subm. by J. C. Knox, Univ. of WisconsinMadison.

$6000 \pm 80$

WIS-450. Blockhouse Creek Drainage Basin 4050 в.c.

Quercus of white oak group, id. by R. C. Koeppen, at $30.5 \mathrm{~cm}$ depth in gravel horizon at base of $229 \mathrm{~cm}$ bank at tributary entrance. Gravel deposit assoc. with max. drought of Atlantic time; finer overlying sediment assumed assoc. with increasing precipitation of SubBoreal and Sub-Atlantic times.

WIS-454. Blockhouse Creek Drainage Basin

Modern

Bone fragments from $\mathrm{B}$ horizon of well-developed dark black paleosol underlying $46 \mathrm{~cm}$ of stratified light colored alluvium exposed in stream bank near center of Blockhouse Creek flood plain. Indicates overlying light colored sediment is related to accelerated hillslope erosion of post-settlement time.

\section{WIS-459. Elvers Creek site}

$1200 \pm 55$

Wood (Quercus sp., red oak) from layer of brushwood peat in paleosol $244 \mathrm{~cm}$ below ground surface immediately above gravel in Elvers Creek branch of Blue Mounds Creek, Wisconsin $\left(42^{\circ} 04^{\prime} 03^{\prime \prime}\right.$ $\mathrm{N}$ Lat, $89^{\circ} 47^{\prime} 44^{\prime \prime} \mathrm{W}$ Long). Coll. 1970 by G. H. Dury, Univ. of Wisconsin-Madison; subm. by G. H. Dury and J. C. Knox. Samples help elucidate probably complex history of cut and fill which includes periglacial sludging before ca. 12,000 B.P. and accumulation of brushwood peat with mainly spruce pollen between ca. 12,000 and 11,000 B.P. At least 2 subsequent episodes of partial re-clearance followed by infilling are tentatively recognized: samples dated appear to represent 2 nd of these infillings. 


\section{Iowa}

\section{WIS-465. Amos Ross site (13PM47)}

$400 \mathrm{~cm}$ sec. of dried pond silt coll. for seed and mollusk study in 1970 on Amos Ross farm in Plymouth Co., Iowa $\left(42^{\circ} 37^{\prime} 30^{\prime \prime} \mathrm{N}\right.$ Lat, $96^{\circ} 06^{\prime} 30^{\prime \prime} \mathrm{W}$ Long). Coll. by R. G. Baker and D. A. Baerreis; subm. by D. A. Baerreis. Sample dated was basswood (Tilia), id. by R. C. Koeppen, from 377 to $383 \mathrm{~cm}$ depth, Level 16, in Col. B.

\section{Yellowstone Park}

\section{WIS-432. Swan Lake Flats}

$13,530 \pm 130$

Marly, carbonaceous, laminated lacustrine silt from 402 to $419 \mathrm{~cm}$ in $500 \mathrm{~cm}$ core from Swan Lake Flats, Yellowstone Park, Wyoming; elev. $2220 \mathrm{~m}\left(44^{\circ} 55^{\prime} \mathrm{N}\right.$ Lat, $110^{\circ} 44^{\prime} \mathrm{W}$ Long). Coll. 1969 by K. Pierce and H. Waldrop; subm. by R. G. Baker. Sample from lowest organic sediments overlying laminated glacial lake sediments. Dates local retreat of Pinedale (Late Wisconsin) ice. Pollen analysis indicates a tundra environment at this time.

\section{Cub Lake, Idaho}

$330 \mathrm{~cm}$ core was obtained in 1969 from Cub Lake, Idaho, $6.44 \mathrm{~km}$ $\mathrm{W}$ of SE corner of Yellowstone Park, elev. $1840 \mathrm{~m}\left(44^{\circ} 7^{\prime} 30^{\prime \prime} \mathrm{N}\right.$ Lat, $111^{\circ} 11^{\prime}$ W Long), by R. G. Baker and H. A. Waldrop; subm. by R. G. Baker.

\section{WIS-438. Cub Lake, Idaho}

$7910 \pm 85$

Fibrous sedge peat from 45 to $50 \mathrm{~cm}$ interval of core. Dates beginning of Pseudotsuga-Pinus contorta dominance in pollen profile. Sediment deposition at site apparently slowed greatly or ceased shortly after this date.

\section{WIS-436. Cub Lake, Idaho}

$10,620 \pm 100$

Dark brown detritus peat from 160 to $165 \mathrm{~cm}$ interval of core. Dates decline in Artemisia pollen usually assoc. with transition from late- to postglacial deposits in Yellowstone Park.

\section{Pyramid Lake, Nevada}

\section{E. Nevada}

Sampling during 1968-69 by S. M. Born, Univ. of Wisconsin-Madison, in Truckee R. valley downstream from Nixon, Nevada, near Pyramid Lake $\left(39^{\circ} 51^{\prime} \mathrm{N}\right.$ Lat, $119^{\circ} 24^{\prime}$ to $119^{\circ} 26^{\prime} \mathrm{W}$ Long), in conjunction with study of lake-level chronology of late Quaternary Pyramid Lake (Born, 1970). Related earlier studies include those of Broecker et al. (1958; 1965) and Morrison and Frye (1965). Results indicate 3 separate lacustrine cycles during past 10,000 yr. Sediments of oldest cycle include only declining lake-level deposits, dating to ca. 8000 B.P. A major low- 
stand is indicated from 8000 to 3500 B.P., resulting in development of a locally prominent angular unconformity and assoc. with widespread deposition of fluvial gravel. This lowstand interval correlates well with high aridity of ca. 6500 B.P. determined by Sears and Roosma (1961) and the Toyeh soil-forming interval which began ca. 5000 B.P. (Morrison and Frye, 1965). A relatively minor lowstand occurred from ca. 2000 B.P. to 1000 yr B.P.; this interval was bracketed by 2 lesser lake-level cycles, from 3500 to 2000 B.P. and from ca. 1000 B.P. to present.

\section{WIS-374. Pyramid Lake, Nevada}

Wood from foreset beds near lake level, $+1168 \mathrm{~m}$.

\section{WIS-377. Pyramid Lake, Nevada}

Macerated plant debris from deltaic sediments near lake level, $+1169 \mathrm{~m}$.

WIS-375. Pyramid Lake, Nevada

Tree bark (probably Ponderosa pine), id. by B. F. Kukachka, Forest Products Lab., Madison, Wisconsin, from foreset sediments, $+1166 \mathrm{~m}$.

\section{WIS-361. Pyramid Lake, Nevada} $2710 \pm 60$

Pieces of wood from foreset beds, $+1159 \mathrm{~m}$. 760 B.C.

WIS-376. Pyramid Lake, Nevada

Wood from fluvial deposits, $+1174 \mathrm{~m}$, short distance upstream from delta.

WIS-378. Pyramid Lake, Nevada

$2270 \pm 55$

320 B.C.

Wood from fluvial deposits, $+1172 \mathrm{~m}$, deposited short distance upstream from delta.

WIS-363. Pyramid Lake, Nevada

Wood from fluvial gravel $+1174 \mathrm{~m}$.

WIS-364. Pyramid Lake, Nevada

Log from fluvial gravel $+1173 \mathrm{~m}$.

\section{F. Northwest Territories}

\section{Southwest Keewatin series}

Charcoal layers capping paleosols $\mathrm{N}$ of tree line in SW Keewatin show 2 periods when forest extended into present tundra: prior to ca. 3500 в.P. and prior to ca. 1000 B.P. (Bryson et al., 1965). During intermediate period, either tree line fluctuated near present tree line, or scattered forest fires occurred (WIS-37, -15, -29, R. 1965, v. 7, p. 405-407). 
Distribution of these paleosols and their dates indicate former extension of Boreal forest into present tundra, but do not show southern limit of tundra after fires which terminated soil-forming episodes.

The following dates were obtained in a continuation of this study, to determine extent of paleosols and terminal fires $S$ of present tree line. Three buried charcoal layers capping paleosols were found in blowout on gentle esker side slope in Kasba, N.W.T., Canada $\left(60^{\circ} 15^{\prime} \mathrm{N}\right.$ Lat, $101^{\circ} 55^{\prime}$ W Long). Coll. 1970 and subm. by C. J. Sorenson and R. A. Bryson. Since soils appeared to have formed under forest, samples believed to be related to fluctuation of forest border to S-ward of present position (Bryson et al., 1965).

\section{WIS-458. Kasba}

$780 \pm 55$

Charcoal, (Picea) id. by B. F. Kukachka, uppermost of 3 buried charcoal layers in blowout. Matrix was aeolian sand over well-stratified sand and gravel.

\section{WIS-460. Kasba}

Intermediate of 3 buried charcoal layers.

WIS-467. Kasba

Lowest of 3 buried charcoal layers.

\section{G. India}

$1810 \pm 55$ A.D. 140

$2940 \pm 50$ 990 B.c.

\section{WIS-405. Lunkaransar Salt Lake, Rajasthan, India $\quad 9260 \pm 115$}

Lacustrine silty clay with dispersed charcoal (B.S.I.P. 1023A/RC-12) at depth $230 \mathrm{~cm}$ from pit in bed of Lunkaransar Salt Lake, Dist. Bikaner, Rajasthan, India (28 $50^{\prime} \mathrm{N}$ Lat, $73^{\circ} 80^{\prime} \mathrm{E}$ Long). Coll. 1968 by Gurdip Singh, Birbal Sahni Inst. of Palaeobot., Lucknow, India; subm. by R. A. Bryson. This level is lowest containing Cerealia pollen. Other dates from same pit have been reported (R., 1970, p. 643).

\section{WIS-415. Didwana Salt Lake, Rajasthan, India}

$$
\begin{array}{r}
2970 \pm 65 \\
1020 \text { B.C. } \\
\delta C^{13}=-23.1 \%
\end{array}
$$

Laminated clay with dispersed charcoal, B.S.I.P. 1024/RC-25, coll. at 120 to $130 \mathrm{~cm}$ depth from profile exposed in pit in sec. of lake deposit at Didwana Salt Lake, Dist. Nagaur, Rajasthan, India $\left(27^{\circ} 22^{\prime} \mathrm{N}\right.$ Lat, 74 35' E Long). Coll. 1968 by Gurdip Singh, Birbal Sahni Inst. of Palaeobot., Lucknow, India; subm. by R. A. Bryson. Sample dated as part of study of postglacial pollen chronology of Rajasthan lake deposits (Singh, 1968) in relation to history of Rajasthan desert (Bryson and Baerreis, 1967).

\section{Khajiar and Rewalsar, Himachal Pradesh, India}

Samples from an area glaciated during Pleistocene in NW India 
were dated to determine time of biostratigraphic and climatic changes during postglacial period in Himachal Pradesh. A $550 \mathrm{~cm}$ core was obtained with a Hiller sampler in lake deposit at Khajiar, Dist. Chamba, Himachal Pradesh, India (32 $32^{\prime} 30^{\prime \prime} \mathrm{N}$ Lat, $76^{\circ} 03^{\prime} 25^{\prime \prime}$ E Long) and a $350 \mathrm{~cm}$ core at Rewalsar, Dist. Mandi, Himachal Pradesh, India $\left(31^{\circ}\right.$ $38^{\prime} \mathrm{N}$ Lat, $76^{\circ} 50^{\prime}$ E Long). Coll. 1969 by Gurdip Singh; subm. by R. A. Bryson.

\title{
WIS-419. Rewalsar, Himachal Pradesh
}

$\mathbf{5 2 0} \pm \mathbf{5 5}$

Coarse organic detritus (B.S.I.P. 1172/RC-29) from 135 to $145 \mathrm{~cm}$ depth.

\section{WIS-417. Rewalsar, Himachal Pradesh}

$1410 \pm 60$

\author{
A.D. 540
}

$\delta C^{13}=-27.0 \%$

Dark brown coarse organic detritus (B.S.I.P. 1172/RC-30) from 280 to $290 \mathrm{~cm}$ depth.

WIS-418. Khajiar, Himachal Pradesh

$1150 \pm 60$ A.D. 800

$\delta C^{13}=-28.5 \%$

Phragmites peat (B.S.I.P. 1171/RC-26) from 143 to $150 \mathrm{~cm}$ depth.

\section{WIS-416. Khajiar, Himachal Pradesh}

$\mathbf{1 8 0 0} \pm \mathbf{5 5}$

Clay with pieces of charcoal (B.S.I.P. 1171/RC-27) from 512 to 522 cm depth.

\section{WIS-428. Khajiar, Himachal Pradesh}

$1830 \pm 50$

Coarse organic detritus (B.S.I.P. 1171/RC-28) from 522 to $532 \mathrm{~cm}$ depth.

\section{REFERENCES}

Bender, M. M., Bryson, R. A., and Baerreis, D. A., 1965, University of Wisconsin radiocarbon dates I: Radiocarbon, v. 7, p. 399-407. p. $522-533$.

University of Wisconsin radiocarbon dates II: Radiocarbon, v. 8,

1969, University of Wisconsin radiocarbon dates VI: Radiocarbon, v. 11, p. $228-235$. p. $335-345$

1970, University of Wisconsin radiocarbon dates VII: Radiocarbon, v. 12,

1970 , University of Wisconsin radiocarbon dates VIII: Radiocarbon, v. 12, p. $640-643$.

Black, R. F., 1969, Valderan glaciation in western upper Michigan: 12th Conf. Internatl. Assoc. Great Lakes research Proc., p. 116-123.

Born, S. M., 1970, Deltaic sedimentation at Pyramid Lake, Nevada: Ph.D. thesis, Univ. Wisconsin-Madison, $234 \mathrm{pp}$.

Broecker, W. S. and Kaufman, A., 1965, Radiocarbon chronology of Lake Lahontan and Lake Bonneville II, Great Basin: Geol. Soc. America Bull., v. 76, p. 537-566.

Broecker, W. S., Kulp, J. L., and Tucek, C. S., 1956, Lamont natural radiocarbon measurements III: Science, v. 124, p. 154-165.

Broecker, W. S. and Orr, P. C., 1958, Radiocarbon chronology of Lake Lahontan and Lake Bonneville: Geol. Soc. America Bull., v. 69, p. 1009-1032.

Bryson, R. A. and Baerreis, D. A., 1967, Possibilities of major climatic modifications and their implications: Northwest India, a case for study: Bull. Am. Meteorol. Soc., v. 48 , no. 3, p. 136-142. 
Bryson, R. A., Irving, W. N., and Larsen, J. A., 1965, Radiocarbon and soils evidence of former forest in the southern Canadian tundra: Science, v. 147, p. 46-48.

Craig, Harmon, 1961, Mass-spectrometer analyses of radiocarbon standards: Radiocarbon, v. 3, p. 1-3.

Crane, H. R., 1956, University of Michigan radiocarbon dates I: Science, v. 124, p. $664-672$.

Hack, J. T., 1965, Postglacial drainage evolution and stream geometry in the Ontonagon area, Michigan: U.S.G.S. Prof. Paper 504B, 40 p.

Morrison, R. B. and Frye, J. C., 1965, Correlation of the middle and late Quaternary successions of Lake Lahontan, Lake Bonneville, Rocky Mountain (Wasatch Range), southern Great Plains, and eastern Midwest areas: Nevada Bur. Mines Rept. 9, $45 \mathrm{p}$.

Sears, P. B. and Roosma, A., 1961, A climatic sequence from two Nevada caves: Am. Jour. Sci., v. 259, p. 669-678.

Singh, G., 1968, A palynological approach towards the resolution of some important desert problems in Rajasthan: Indian Hydrology, v. 3, no. 1, p. 111-126.

West, R. G., 1961, Late and postglacial vegetational history in Wisconsin, particularly changes associated with the Valders readvance: Am. Jour. Sci., v. 259, p. 766-783.

Wilford, L. A., 1955, A revised classification of the prehistoric cultures of Minnesota: Am. Antiquity, v. 21, no. 2, p. 140-141. 